\title{
PROBLEMS OF INFORMATIONAL SUPPORT OF VALUATION ACTIVITY
}

\section{Valentyna Panasyuk ${ }^{1}$ \\ Oksana Chereshnyuk ${ }^{2}$}

DOI: https://doi.org/10.30525/978-9934-588-53-2-8

Abstract. The accounting estimations are connected with the determination of fair market value of assets, the formation of the doubtful debts allowance, the vacation compensation reserve, the formation of warranty obligations, the defining of net realizable value of stocks, etc. In addition, it should be noted that inflation distorts the financial statements of the enterprise, and the size of the assets value, according to its data, may differ sharply from their market value. This requires a periodic revaluation of property, which allows you to increase the feasibility of financial statements and serves as the basis for making sound management decisions.

Professional self-regulatory organizations of valuators in this country are not recognized as the appraisers, as it is done throughout the world. Any of their initiatives regarding the possible distribution of duties and powers among these organizations and the state regulator are blocked by the latter, which defines only the responsibilities, but does not confer any substantive rights. This is due to the fact that the governmental authorities, nevertheless, control the activities of self-regulatory organizations.

To remedy the situation, first of all, any certification of the appraisers should be abandoned. That is, the state regulator must finally abolish the existing practice of issuing certificates to the appraisers. Then, it is necessary to increase the range of appraisers - the subjects of legal relations in the field of valuation and balanced distribution of rights, responsibilities and corresponding powers among them. The next step is to abandon the existing practice of the evaluative dualism model.

\footnotetext{
${ }^{1}$ Doctor of Economic Sciences, Professor,

Ternopil National Economic Univesity, Ukraine

${ }^{2}$ Candidate of Economic Sciences,

Senior Lecturer at the Department of Economic Evaluation and Business Audit,

Ternopil National Economic Univesity, Ukraine
}

(C) Valentyna Panasyuk, Oksana Chereshnyuk 
Thus, the appraisers can be conditionally divided into direct and indirect participants of the valuation activities. The direct participants include those individuals, which directly carry out practical work on the determination of value, namely, professional valuators. The indirect appraisers include those, which influence the valuation process indirectly but are not its direct participants.

The following multicriteria tasks for property valuation need automatization: sales comparison procedures; algorithms of calculation and forecasting of cash flow, rates of capitalization and discounting; correlationregression analysis of the relationship of value and basic technical and economic indicators.

\section{Introduction}

Every year, the number of professional audit services grow, which, to a certain extent, opens up new opportunities for both the performers and customers of these services. The result of the development of the market for audit services is that modern audit firms perform a fairly large range of works, including valuation of assets. The emergence of this service is due to the reflection in the accounting of operations which are, in whole or in part, based on the subjective opinion of the performers. Such operations require the use of accounting estimations, which may be caused by the bias of the accounting staff.

The accounting estimations are connected with the determination of fair market value of assets, the formation of the doubtful debts allowance, the vacation compensation reserve, the formation of warranty obligations, the defining of net realizable value of stocks, etc. In addition, it should be noted that inflation distorts the financial statements of the enterprise, and the size of the assets value, according to its data, may differ sharply from their market value. This requires a periodic revaluation of property, which allows to increase the feasibility of financial statements and serves as the basis for making sound management decisions. The mentioned circumstances require of the auditors-valuators to have thorough knowledge of the provisions of regulatory legal acts of valuation and the ability to apply methodological approaches, methods and valuation procedures that make the basis for the determination of the market value of assets.

It should be noted that in the process of valuation it is necessary to be guided by different regulatory and legal bases, namely, by laws and 
regulations (standards, methodologies, instructions, orders, etc.) issued by the executive authorities on the basis of the law and in accordance with its provisions. The State Property Fund of Ukraine engages other governmental authorities, self-regulatory organizations of appraisers, the most authoritative valuators, scientific and other institutions to elaborate national regulations.

\section{Regulation of valuation activities}

First of all, the activity of the valuator is based on the provisions of the Law of Ukraine "On valuation of property, property rights and professional valuation activities in Ukraine" [2]. It defines the legal aspects of the valuation of property, property rights and professional valuation activity in Ukraine, administers the process of state and public regulation, provides for the establishment of the independent property valuation system to protect the legitimate interests of the state and other economic entities. The legal basis for the land valuation in Ukraine, which is used as a guidance for the professional valuation, is determined by the Law of Ukraine "On land valuation" [3].

The study of the evolution of the valuation activities development suggests that at the first stage, namely, before the adoption of the above enlisted laws, while performing their activities, the valuators relied on the practical recommendations of foreign valuators, and also used the methods of the State Property Fund of Ukraine.

The second stage, which begins in 2001, is considered the stage of the professional valuation activities formation. This particular stage is marked by the adoption of laws on the valuation of property and land, the elaboration of national standards for valuation, the development of the methodology on valuation of various objects. It should be noted that the completion of these regulations was based on the International Valutaion Standards (IVS), which are basic in defining the concepts and main principles of valuation activities [4]. IVS are recognized throughout the world. However, their provisions are of a recommendatory nature. They are issued by the International Valuation Standards Council, which brings together professional valuation organizations from more than 50 countries. It is worth mentioning that the international standards are constantly being reviewed.

The national standards for property valuation, firstly, include: the definition of concepts, the description of the valuation principles, the basic 
principles and methodological approaches to the valuation of the relevant property, taking into account its features and purpose of valuation, the requirements for the preparation of a report on the property valuation and the procedure for its review; and, secondly, determine the cases of application and those of restrictions in the application of methodological approaches by the valuator in calculating the value of various components of property.

Under present conditions, there are four standards in Ukraine. The first national standard "General Principles of Property Valuation and Property Rights" provides the interpretation of the general terms used in valuation activities, describes the bases of valuation and the procedure for its determination, describes the essence of methodological approaches, as well as defines the requirements for the independent valuation, drawing a valuation report and preparation of the conclusion regarding the property value [7].

The second national standard "Real estate valuation" reflects the methodological approaches and peculiarities of their application in relation to the definition of the value of various real estate units [8].

The third national standard "Valuation of integral property complexes" provides a description of income, comparative and property approaches and specifies the peculiarities of their application in estimating the value of the enterprise as an integral property complex and defines the requirements for the preparation of the valuation report [10].

It should be noted that the fourth national standard "Valuation of Intellectual Property Rights" is mandatory for the purposes of valuation of the proprietary rights of intellectual property, as well as for determining the amount of losses caused by their improper use [9].

The provisions of the laws and standards for the property valuation are detailed in the methodologies, the main of which are:

"Methodology for leased objects valuation" defines the valuation features and determination of the value of leased property, as well as the use of the results of such valuation for the calculation of rent [11];

"Methodology for commodity expertise and valuation of road vehicles" establishes a sequence of calculation of the road vehicles value, regulates the principles, methods, procedures of valuation, as well as the requirements for the execution of its results [13]; 
"Methodology for property valuation" is necessary for carrying out the valuation of various types of property during privatization processes and in other mandatory cases [5].

At the third stage of the valuation activities development, which covers the period from 2008 up to the present, the attempts have been made to change the regulatory framework of valuation, increase the level of training of professional valuators, select certain types of valuation. However, in general, according to some scientists, the necessary positive changes have not been made [6].

It is worth pointing out that the current legal framework of valuation plays a very important role in the development of independent professional valuation activities. However, it is difficult to name it a set of mutually agreed documents that, in content and structure, meets the challenges of the present. The dynamics of society and national economy requires the continuous development of valuation practice. The current national standards do not reflect the accumulated experience of both national and international practice. By the way, the international valuation standards are amended and supplemented every two years. Following the editions of 2009, 2011, 2013, 2015, January 2017, the International Valuation Standards Council released the information as for the new International Valuation Standards for 2017 (IVS 2017) to public on its official website.

The study of the regulatory framework governing of the appraisers activities, the review of special literature have revealed some problems that hinder the development of national valuation activities.

First of all, let us consider one of the key concepts of the methods of independent property valuation, i.e. the appraiser, and analyze its role and place in the process of valuation.

The appraisers are:

- central and local authorities;

- valuators are the natural individuals, which are registered and are members of the Unified State Register of Appraisers;

- economic entities: the natural individuals are entrepreneurs, which are registered in accordance with the procedure established by the law, as well as the legal entities, regardless of their organizational and legal form and ownership, which carry out economic activities and employ at least one valuator registered in the Unified State Register of Appraisers; 
- self-regulatory community-based organizations of valuators;

- customers of the valuation are the legal entities and natural individuals, at the initiative of which and on the basis of a written agreement the valuation of a particular object is carried out;

- consumers of valuation services are the legal entities and natural individuals, executive authorities which use the information outlined in the independent valuation report.

The list of the appraisers, in accordance with article 5 of the Law of Ukraine "On valuation of property, property rights and professional valuation activities in Ukraine" is rather limited. The law-maker assignes the status of an appraiser only to central and local authorities, which manage and dispose of state property and/or the property that is in the communal ownership and are entitled to carry out valuation activities, and which employ the vauators, as well as the separate economic entities, which received a certificate from the state that is an analogue of a license for carrying out the economic activity.

Thus, by law, only two categories of persons - subjects of legal relations are qualified as the appraisers, which contradicts the general theory of law.

\section{Practical implementation of the evaluation process}

As a result, in Ukraine, a model of valuation dualism has been introduced at the fundamental level, that is illustrative only for this country. According to this model, the provision of independent valuation services and drawing up a report on property valuation can be carried out simultaneously both on behalf of the valuator and the "certified appraiser".

If there are only two categories of appraisers, then the rights, responsibilities, and powers should be distributed among the specified categories of subjects of legal relations. At the first glance, this situation can be considered as a small problem. However, it has a number of negative consequences. Let us try to analyze the most obvious of them.

Professional self-regulatory organizations of valuators in this country are not recognized as the appraisers, as it is done throughout the world. Any of their initiatives regarding the possible distribution of duties and powers among these organizations and the state regulator are blocked by the latter, which defines only the responsibilities, but does not confer any substantive rights. This is due to the fact that the governmental authorities, nevertheless, control the activities of self-regulatory organizations. 
Also, a valuator in Ukraine is not considered a self-sufficient subject of legal relations, despite higher education, taking the necessary training course and the period of internship, passing a state qualifying examination and subsequent obtaining a qualification certificate, which confirms a sufficient professional level of the valuator's preparation for the independent valuation, registration in the state register of appraisers and obtaining the corresponding certificate, as well as the regular improvement of his/her professional qualities. The Law of Ukraine "On valuation of property, property rights and professional valuation activities in Ukraine" stipulates that a report on property valuation shall be signed not by a valuator, which directly carries it out, but by the head of an economic entity as a "certified appraiser". The absence of the legal status assigned to the appraiser by the valuator creates problems related to the unbalanced distribution of rights, powers, responsibilities and the level of responsibility for the quality of the services rendered between the appraiser and the "certified appraiser".

In the world valuation practice, this problem is solved in the following way. The valuator is a natural individual, a self-sufficient subject of the legal relations which has the appropriate education, posseses certificates, permissions, licences registered in the prescribed manner (etc.), is fully responsible for the results of his/her work (the valuation carried out). Therefore, he/she solely draws up and signs the report on property valuation. The economic entity as an appraiser is also considered an important subject of legal relations. After the agreement with the customer has been concluded, in accordance with the law, the appraiser does not bear any responsibility for the results of the valuation itself. It is responsible only for the improper performance. In this case, the activity of such an economic entity does not require licensing, appropriate certification, etc. The head of the entity mentioned above only signs the valuation agreements, the acts of transfer and acceptance, the accompanying letters to the valuation customers on the report drawn up and signed by the valuator.

The existence of the unique concept of the "appraiser certificate" in the national legislation leads to the artificial limitation of the list of appraisers, undervalues the social role of the valuator him/herself, places him/her in place of the appraiser, as an economic entity that holds a certificate, which is only a kind of license. 
Such situation has led to a number of negative consequences, the most obvious of which are the following:

- existence of two state registers: the register of valuators and the register of appraisers. The appraiser certificate is issued to the business entity for a term of three years with the right of subsequent reissuance, which requires the additional documents;

- the actual provision of services for the professional valuation of objects not by the valuators, but by the appraisers - economic entities. The valuator is compelled to necessarily coordinate the Property Valuation Report with the head of the appraiser. In his/her turn, the head him/herself may not be a valuator, and, therefore, not be responsible for the valuation results. However, he/she may act in the interest of the valuation customers or other interested parties, influencing the valuator. This situation creates a threat of unscrupulous participants emergence at the market, which are not subject to control because they are not a part of the valuation community;

- the insolvency of the state regulator to influence the activity of individual appraisers - economic entities providing the services of poor quality. This is explained by the fact that the current legislation potentially restricts the State Property Fund as for the possibility of depriving the appraisers - economic entities of the right to be engaged in professional activities. If the appraiser certificate of the economic entity is cancelled, then, in accordance with Article 20 of the current Law on valuation, its renewal will be carried out in the same manner as it is established for its obtaining (issuance). Namely, after the cancellation of the certificate, the appraiser may apply for a new one on the next day. And if the requirements of Article 19, which regulates the procedure for obtaining a certificate, are complied with, then the State Property Fund of Ukraine is obliged to issue a new document to the applicant. Thus, one can say that the certificate is not the document, on the basis of which it is possible to regulate the quality of valuation services [2].

To remedy the situation, first of all, any certification of the appraisers should be abandoned. That is, the state regulator must finally abolish the existing practice of issuing certificates to the appraisers. Then, it is necessary to increase the range of appraisers - the subjects of legal relations in the field of valuation and balanced distribution of rights, responsibilities and corresponding powers among them. The next step is to abandon the existing practice of the evaluative dualism model. 
Based on the analysis of the positions of scientists, we support the following classification of the appraisers (Figure 1).

Thus, the appraisers can be conditionally divided into direct and indirect participants of the valuation activities. The direct participants include those individuals, which directly carry out practical work on the determination of value, namely, professional valuators. The indirect appraisers include those, which indirectly influence the valuation process but are not its direct participants.

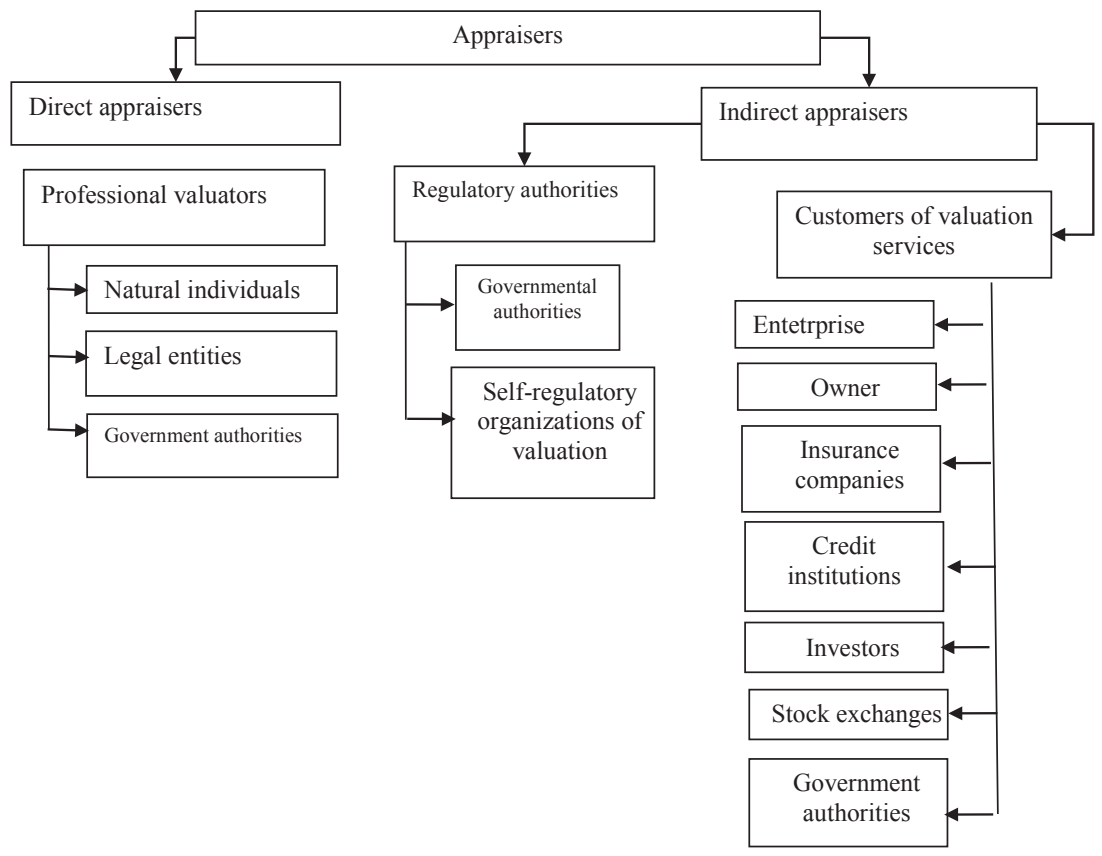

Figure 1. Classification of appraisers [6]

The formation and improvement of the regulatory framework for valuation of all types of property rights requires the maximal unification of the conceptual apparatus and terminology used in the practice of valuation activities and bringing it into line with the conceptual apparatus and terminology of accounting, taxation, as well as the terms of international 
valuation standards. Indeed, there is a discrepancy in the treatment of the categories of "income", "net operating income", "cash flow" by the national standards of valuation and accounting standards.

\section{Information provision of the valuation process}

In addition, it is necessary to arrange the formation of objective information provision of the valuation process which would serve as a reliable, operational database for determining the market value of enterprises and the value of other objects of valuation, and which would include: directories on costs; data on the prices for basic production equipment, tools and inventory; information on the prices of offers, sales and real estate transactions; informative data on the indicators of profitability and risk for different types of business, etc.

Currently, there are some state and non-state structures that collect data on sales transactions of the respective property. However, these data are incomplete, disjointed by departments and types. It is rather difficult to obtain the information from relevant organizations regarding the property objects which are the subject of sales contracts and their owners. Therefore, the question of systematization, creation and further use of single database as the substantiated information is extremely important. Their successful resolution requires the unification of all the available databases for the purpose of qualitative practical application in the activities of valuation firms. At the present moment, the mentioned above firms, in accordance with their tasks, create databases, the composition and structure of which are different and incomplete. Because of this, the generalization of the information for the purposes of further practical use becomes impossible. In order to create a unified information database, it is necessary to develop forms of standardized description of data by classes of valuation objects. It will help to create the electronic version of the database of property objects by using a common software, which, in its turn, will allow further automation of database creation with the use of modern information technologies.

Thus, the creation of a unified database system will help to efficiently carry out the valuation and improve the quality of valuation services [1].

The process of valuation of objects can be presented in the form of a substantiated and systematic procedure using the well-known approaches and methods. It is characterized by multivariance, multiplicity of parameters 
and computational complexity. This requires sound knowledge and skills of the valuators to apply economic and mathematical, statistical methods and technical means (computers, devices for collecting, transmitting, and outputting information, etc.) in practice.

\section{Conclusions}

The described situation necessitates the development and implementation of modern computer technologies and software products. The following multicriteria tasks for property valuation need automatization: sales comparison procedures; algorithms of calculation and forecasting of cash flow, rates of capitalization and discounting; correlation-regression analysis of the relationship of value and basic technical and economic indicators, etc.

Another important direction in increasing the quality of valuation services is to improve the methodological provision of works for the calculation of the cost of various objects. The methodological instructions, which would form the generally accepted procedure for calculating the amendments to the value of comparables, the choice of criteria for selecting comparative factors, the practical use of statistical methods of data processing, are needed.

Improving the regulatory framework of the evaluation activity and expanding the content of its components will allow to optimize the time and search for the necessary elements. This approach will help to avoid inaccuracies in the interpretation of concepts.

Currently, there are some state and non-state structures that collect data on sales transactions of the respective property. However, these data are incomplete, disjointed by departments and types. It is rather difficult to obtain the information from relevant organizations regarding the property objects which are the subject of sales contracts and their owners. Therefore, the question of systematization, creation and further use of single database as the substantiated information is extremely important. Their successful resolution requires the unification of all the available databases for the purpose of qualitative practical application in the activities of valuation firms. Improvement of the evaluation activity will allow the unification of information from two sources, namely the state registers and the data of the subjects of the evaluation activity.

Displaying the results of the evaluation has many features in accounting. Therefore, the proposed enhancement of the valuation activity will make it 
more accurate to reflect the value of the accounting entities and eliminate the re-correction of errors. This approach will absorb the informativeness of accounting and more accurately determine the value of the enterprise.

\section{References:}

1. Efremova, L. V. (2013). Problemy vdoskonalennja metodologhiji ta procedur ocinky majna [Problems of improving the methodology and procedure of property valuation]. Business Inform, no. 1, pp. 249-251. (in Ukrainian)

2. The Law of Ukraine on valuation of property, property rights and professional valuation activities in Ukraine [Zakon Ukrajiny "Pro ocinku majna, majnovykh prav ta profesijnu ocinochnu dijaljnistj v Ukrajini”] № 2658-III with amendments and supplements, July 12, 2001. Available: http://zakon2.rada.gov.ua/laws/show/2658-14

3. The Law of Ukraine on land valuation [The Law of Ukraine on land valuation] № 132-IX, current version September 20, 2019. Available: https://zakon.rada.gov.ua/ laws/show/1378-15

4. International Valuation Standards. Mizhnarodni standarty ocinky. Official website of OMEGA. [Online]. Available at: http://www.omegaocenka.ru/document/ standart_MCOplan.shtml

5. The Methodology for property valuation, approved by the resolution of the Cabinet of Ministers of Ukraine [Postanova Kabinetu Ministriv Ukrajiny "Pro zatverdzhennja Metodyky ocinky majna"] No.1891, December 10, 2003. Available at: http://zakon3.rada.gov.ua/laws/show/1891-2003-\%D0\%BF

6. Opara, V. M. (2016). Standartization in the field of land valuation [Standartyzacija v ghaluzi ocinky zemelj]. Bulletin of the V.N. Karazin Kharkiv National University, issue 44, pp. 137-141. (in Ukrainian)

7. On the approval of National Standard No 1 "General principles for the valuation of property and property rights" [Nacionaljnyj standart \#1 "Zaghaljni zasady ocinky majna i majnovykh prav"] No 1440, Resolution of the Cabinet of Ministers of Ukraine, September, 10, 2003. Available at: http://zakon5.rada.gov.ua/laws/ show/1440-2003-\%D0\%BF

8. On the approval of National Standard No 2 "Real estate valuation". Resolution of the Cabinet of Ministers of Ukraine [Nacionaljnyj standart \# 2 "Ocinka nerukhomogho majna"] dated 28.10.2004. No 1442. Available at: http://zakon5.rada.gov.ua/laws/show/1442-2004-\%D0\%BF

9. On the approval of National Standard No 4 "Valuation of intellectual property rights" [Nacionaljnyj standart \#4 "Ocinka majnovykh prav intelektualjnoji vlasnosti']. Resolution of the Cabinet of Ministers of Ukraine dated October 03, 2007. Available at: http://zakon2.rada.gov.ua/laws/show/1185-2007-\%D0\%BF/conv

10. On the approval of National Standard No 3 "Valuation of integral property complexes" [Nacionaljnyj standart \#3 "Ocinka cilisnykh majnovykh kompleksiv"]. Resolution of the Cabinet of Ministers of Ukraine dated 29.11.2006. No 1655. Available at: http://zakon3.rada.gov.ua/laws/show/1655-2006-\%D0\%BF

11. On the approval of the Methodology for leased objects valuation, the Procedure for redemption of turnaround material by the tenant and the Procedure 
for providing loans of funds and securities to the lessee [Pro zatverdzhennja Metodyky ocinky vartosti objektiv pryvatyzaciji]. Resolution of the Cabinet of Ministers of Ukraine dated August 10, 1995 No 629 with amendments and supplements. Available at:http://zakon4.rada.gov.ua/laws/show/629-95-п

12. On the approval of the Methodology for valuation of intellectual property rights [Pro zatverdzhennja Metodyky ocinky majnovykh prav intelektualjnoji vlasnosti]. Order of the State Property Fund of Ukraine dated 26.06. 2008 No 740. Available at: http://zakon3.rada.gov.ua/laws/show/z0726-08

13. On the approval of the Methodology for commodity expertise and valuation of road vehicles [Pro zatverdzhennja Metodyky tovaroznavchoji ekspertyzy ta ocinky kolisnykh transportnykh zasobiv]. Order of the State Property Fund and the Ministry of Justice of Ukraine dated 24.11.2003. No 142/5/2092 with amendments and supplements. Available at: http://zakon0.rada.gov.ua/laws/show/z1074-03 